УДК 321.7

DOI https://doi.org/10.32849/2663-5313/2019.8.31

\title{
Олег Олійник,
}

канд. юрид.наук,

старший викладач кафедри права

факультету права та сочіально-інформачійних технологій

Миколаївського міжрегіонального інституту розвитку людини

Відкритого міжнародного університету розвитку людини «Украйна»

\section{ХАРАКТЕРИСТИКА НЕГАТИВНОГО ВПЛИВУ НА ДЕМОКРАТІЮ В УКРАЇНІ}

У статті розкрито сучасні важелі негативного впливу на демократію в Украӥні. Визначено поняття демократії як сукупності керівних ідей, форм та особливостей управління в державі, за яких влада належить народові, тобто з використанням правових механізмів обов'язкової участі народу в державно-управлінських та суспільних процесах, з метою розвитку соиіального, політичного та культурного життя населення, приниипів правової держсави, забезпечення прав, свобод та інтересів осіб та суспільства в державі. Розкрито, що основними сучасними важелями негативного впливу на демократію в Украӥні є: 1) проведення військових дій на території України; 2) нестабільність політичного життя; 3) сочіально-економічна, політична, культурна криза; 4) часті порушення прав, свобод та законних інтересів осіб в українському суспільстві; 5) корупиія та відсутність ефективних антикорупиійних органів; 6) неефективна судова система; 7) неякісна інформаційна політика в державі, внаслідок чого триває гібридна війна; 8) низький розвиток локальної демократіі; 9) посягання на свободу слова, в тому числі посягання на життя та здоров'я журналістів, правозахисників та активістів, що пов'язані з професійною діяльністю; 10) недосконалість правового регулювання, несправедливі та негуманні правові норми або їх відсутність; 11) відсутність взаємозв'язку та сочіального діалогу між державою та громадськістю; 12) порушення у виборчих процесах; 13) переважання захисту інтересів більш фінансового-сталих верств населення, нерівність у суспільстві. Доведено, що важелі негативного впливу на демократію в Україні можна прибрати шляхом проведення ефективної державної політики у всіх сферах суспільства, припинення військових дій на території України, розвитку освіти та правосвідомості в суспільстві, дотримання приниипу рівності, створення тісного взаємозв'язку між державою та громадськістю, забезпечення захисту прав, свобод та законних інтересів осіб, особливо журналістів, активістів та правозахисників, та загалом формування демократії як форми народовладдя.

Ключові слова: демократія, інформаційна політика, народовладдя, політика, права, свободи, фактори впливу.

Постановка проблеми. Україна перебуває на складному етапі суспільного життя, що підкреслюється економічною, політичною та соціальною кризою. Революційні виклики в українському суспільстві зумовили необхідність проведення різноманітних реформ, які повинні забезпечити основні права, свободи та законні інтереси осіб у суспільстві. Реформи в Україні повинні проводитися з дотриманням провідної форми управління державою демократії. Основним суб'єктом демократії є народ, який обов'язково бере участь у суспільно-політичному житті держави.

Революція Гідності вказала, що диктаторський режим у правовій державі неможливий, українська демократія показала свою волю та змінила тодішню владу. Однак нині в Україні все-таки є проблеми в дотриманні демократії, пов'язані 3 несправедливістю в суспільстві, посяганнями на свободу слова та загальною незахищеністю осіб у суспільстві.

Таким чином, враховуючи проведення євроінтеграційних процесів в українському суспільстві, реформ у суспільному житті, необхідно комплексно дослідити негативні важелі впливу на демократію в Україні та розкрити шляхи їх уникнення.

Аналіз останніх публікацій. Проблеми забезпечення демократії в Україні досліджували такі науковці, як В. Береза, В. Богатирець, С. Власенко, М. Головатий, О. Громико, О. Долженков, В. Кривошеїн, Н. Латигіна та інші. Однак сучасна політична, економічна та соціальна нестабільність в Україні зумовлює необхідність дослідження важелів негативного впливу на демократію в Україні. 
Мета статті полягає в тому, щоб на основі теорії права, позицій юристів та сучасних публіцистичних джерел визначити сучасні важелі негативного впливу на демократію в Україні.

Виклад основного матеріалу. Для визначення важелів негативного впливу на демократію варто коротко охарактеризувати загальне поняття «демократія». Тлумачний словник визначає демократію (від грецької народовладдя, від народ і влада) як форму управління, політичний лад, при якому верховна влада належить народові; форму, принцип керівництва яким-небудь колективом, при якому забезпечується активність і широка участь цього колективу у здійсненні всіх заходів [2, с. 239]. Теорія демократії не має єдиного наукового джерела. Ї̈̈ витоки простежуються в працях теоретиків Античності (Платон, Арістотель, Перікл, Цицерон та ін.), Нового часу (Ш. Монтеск'є, Дж. Локк, Ж.-Ж. Руссо), великий внесок у iï становлення був зроблений батьками-засновниками США (Т. Джефферсон, А. Гамільтон, Д. Медісон, Дж. Джей, Б. Франклін). Сучасна демократична теорія представлена безліччю шкіл і напрямів, кожна з яких володіє солідною методологією і користується значним авторитетом серед певних сегментів наукової спільноти [14; 8, с. 221-229].

Щодо сучасних понять «демократія», то, наприклад, В. Береза вказує, що демократія є сутністю громадянського суспільства й основою держави, його становлення відбувається у тісному зв'язку зі становленням правової, соціальної, демократичної держави. Сутність демократії полягає у забезпеченні законних прав людини. Особа в такому суспільстві має гарантоване право вільного вибору нею тих чи інших форм економічного і політичного буття, ідеології, світогляду, а також можливість вільно висловлювати свої думки, обмінюватися поглядами [1, с. 151]. У політико-правовій теорії, як вказує Н. Латигіна, визначення поняття демократії має кілька вимірів, які виявляють іï сутність повною мірою: по-перше, демократія - це форма держави; по-друге, демократія - це форма плюралістичної організації громадянського суспільства і політичних партій, що репрезентують його інтереси, профспілок та інших громадських організацій; по-третє, демократія виступає як політичний світогляд і відповідний суспільно-політичний рух [11, с. 29].

М. Головатий переконує, що демократія може і розглядається фактично в трьох основних інтерпретаціях. Перша інтерпретація: демократія подається і пояснюється як народовладдя. Друга інтерпретація: демократія - це те, що пов'язане і характеризується відповідним державним влаштуванням. Йдеться про визнання народом джерела влади на принципах рівності і свободи. Третя інтерпретація демократії має місце тоді, коли йдеться про колективну діяльність усіх громадян, їхні рівні права та обов'язки в партії, об'єднанні, групі тощо. У найзагальнішому плані поняття «демократія» використовується як: а) характеристика історичних типів державно-політичного устрою; б) означення політичного процесу з відповідними методами і процедурами, що забезпечують участь народу в управлінні державою, всіма суспільними справами; стосовно організації та діяльності окремих політичних і соціальних структур у різних сферах суспільного життя [5, с. 32-33].

Таким чином, демократія як правове явище - це сукупність керівних ідей, форм та особливостей управління в державі, при якому влада належить народові, тобто з використанням правових механізмів обов'язкової участі народу в державно-управлінських та суспільних процесах з метою розвитку соціального, політичного та культурного життя населення, принципів правової держави, забезпечення прав, свобод та інтересів осіб та суспільства в державі.

Якщо звернутися до важелів негативного впливу на демократію, то для початку варто зазначити, що за роки незалежності в Україні прагнення до утвердження європейських демократичних цінностей перетворилося на фікцію, оскільки був відсутній діалог між владою та громадянським суспільством; відносини правлячої еліти й опозиції перетворилися на фарс, бо кожна сторона намагалася перетягнути увагу на себе, що посилювало делегітимізацію влади; влада й пересічні громадяни існували незалежно один від одного - вони нібито існували в паралельних світах. «Революція гідності» продемонструвала нездатність органів державної влади вести діалог із громадянським суспільством. Відмова керівництва держави від публічних обговорень та експертних консультацій у процесі ухвалення рішення про зміну євроінтеграційного стратегічного курсу України, грубе порушення прав і свобод людини і громадянина, застосування сили для врегулювання конфлікту інтересів спричинили загрозу існуванню України як конституційної держави. За таких умов відбулося згортання соціально-економічних реформ у тому числі у сфері місцевого самоврядування та розвитку локальної демократії. Нині під впливом Революції гідності відбувається трансформація політичної і правової культури як мас, так і правлячої еліти у бік європей- 
ських демократичних цінностей [9, с. 37-58].

Щорічний звіт міжнародної правозахисної організації Freedom House «Свобода у світі 2019» [12] вказує на зниження рівня глобальних політичних і громадянських свобод [13].

2019 року Freedom House визнала Україну «частково вільною» країною, а її окуповану Росією частину Крим - «невільною територією». Дослідники стверджують, що хоча наша країна і роком раніше була в такому статусі, рівень свобод у державі ще більше знизився. Це відбулося, зокрема, через такі ключові моменти 2018 року: 1. Правозахисні групи задокументували понад 50 нападів на активістів i правозахисників протягом перших 9 місяців року. Також мали місце жорсткі збройні напади на ромську меншину 3 боку націоналістичних угруповань. Розслідування цих випадків взагалі відбувалося тільки після значного тиску з боку суспільства. 2. Парламентарі і президент ухвалили законодавчі акти про створення Антикорупційного суду. Проте внутрішні і міжнародні спостерігачі висловили стурбованість процесом відбору 39 суддів, які повинні увійти до складу суду. 3. На Донбасі продовжилися нерегулярні бойові дії. Організація Об'єднаних Націй доповіла про загибель понад 3 тис. цивільних осіб від часу початку конфлікту в 2014 році. 4. У листопаді в 10 регіонах України було на 30 днів запроваджено воєнний стан після захоплення Росією 24-х українських моряків біля берегів Криму. Положення указу про воєнний стан призвели до обмеження свободи слова та зібрань, хоча їх і не було на практиці [12; 7].

Freedom House, як і десятки років до цього, вірить, що ситуацію зі свободою у світі можна змінити, якщо: - дотримуватися прав людини і закону щодо мігрантів та біженців; інвестувати у громадянську освіту; - заохочувати і захищати журналістів та свободу слова; - посилити заходи щодо захисту від іноземного впливу; - припиняти спроби порушення виборчого законодавства; - запроваджувати адресні санкції за порушення прав людини та корупцію; - створювати альянси 3 іншими демократичними країнами; - протистояти зловживанням міжнародних інститутів (маніпуляції Інтерполом, Радою ООН та ін.) [12; 7].

Синтезувавши основні причини деінституціоналізації демократії в Україні, С. Власенко визначив іï основні ризики, які вона має подолати для функціонування вітчизняної системи державного управління. До таких ризиків вчений відносить: фактичне відмежування громадськості від державної влади, що суттєво знижує ії легітимність, та несформованість демократії як форми народовладдя; бюрократизацію та олігархізацію, які утверджуються в результаті запровадження жорсткої ієрархічної системи державного управління; потужний вплив на процеси формування та реалізації державної політики найбільш вагомих фінансово-економічних груп суспільства, що призводить до зрощення бізнесу з органами державної влади; поширення в суспільстві тоталітарних тенденцій, унаслідок чого органи виконавчої влади перебирають на себе основні законодавчі ініціативи; зростання політичної нерівності у суспільстві, що позбавляе громадян можливості вільної участі у політичних та державно-управлінських процесах, а також суттєво розширює параметри свободи представницьких органів державної влади; політичне маніпулювання громадськістю з метою реалізації власних вузькокорпоративних інтересів [4, с. 131-137].

Щодо особливостей побудови демократії в Україні, то Н. Латигіна виокремлює такі проблеми: 1) демократичні зміни розпочалися на тлі несформованості багатьох передумов переходу до демократії: в економіці, соціальній сфері, культурі, політиці; 2) гетерогенність українського суспільства (структурованість за соціально-економічними, ідеологічними, етнічними, релігійними, регіонально-культурними, мовними ознаками, відмінності у зовнішньополітичних орієнтаціях тощо) ускладнює побудову стабільної демократії; 3) драматизм ситуації посилює те, що Україні необхідно одночасно розв'язувати два складних завдання: долати безліч негативних наслідків авторитарного минулого, розбудовуючи демократію, і одночасно вирішувати складні соціально-економічні проблеми; 4) безпорадність влади в умовах соціально-економічної кризи девальвує демократичні цінності і принципи владарювання в очах пересічних громадян; показником розчарування у демократії можна назвати тенденцію до «полівіння» електорату, зростаючу аполітичність молоді; 5) не сприяє зміцненню демократії і політична еліта, яка не спромоглася встановити між собою консенсус навіть заради визнання спільної та рівної зацікавленості в забезпеченні демократичних інститутів і виробленні спільної програми демократичних реформ; 6) відсутність всенародного обговорення комплексних проектів демократичних перетворень, нерозвиненість форм контролю за владою та посадовими особами відводить населенню роль пасивного спостерігача кулуарних зіткнень та соціально-економічних експериментів у суспільстві, посилюючи цим масове соціальне відчуження; 7) демократія форму- 
ється протягом тривалого часу, і брак в українському суспільстві реальних позитивних змін породжує масове соціальне нетерпіння, фрустрації [10, с. 53-62].

Таким чином, міжнародні незалежні громадські інституції, аналізуючи стан дотримання демократії в українському суспільстві, вказують на активні спроби підвищити рівень забезпечення демократії в країні, однак об'єктивні причини (війна на території України, зміни в політичному житті, олігархія, укорінена корупція) негативно впливають на дотримання прав, свобод та законних інтересів осіб в українському суспільстві.

Перехід до інформаційного суспільства передбачає системні зміни в соціальній, економічній, політичній, правовій, культурній структурі суспільства. 3 огляду на масштабність і глибину передбачуваних змін стає зрозумілим, що вони можуть бути здійснені тільки за умови активного сприяння органів державного управління, оскільки роль держави завжди полягає в координації всіх процесів, що стосуються суспільства. Разом із цим роль організатора реалізації проекту має належати не тільки органам державного управління, а й громадським організаціям, громадській ініціативі. В Україні всі ці процеси відбуваються хаотично, несистемно, інколи спонтанно та ситуаційно, ще й досі надзвичайно важливою проблемою, яка стоїть на заваді становлення е-демократії в Україні, є відсутність належного бюджетного фінансування [6, с. 42-47].

Також натепер недостатньо вивчено i конкретизовано структуру політичної системи суспільства, що, у свою чергу, породжує різні точки зору на роль масмедіа в цій підсистемі суспільства. Іншою передумовою для існування громадських 3МІ є правові гарантії й переваги, що формуватимуть умови діяльності таких медіа в суспільстві й забезпечуватимуть необхідний для функціонування справжньої демократії громадський контроль за владою, на противагу заангажованим ЗМІ (державним, партійним, приватним). Водночас поєднання грамотного правового регулювання і реального функціонування передбачає наявність розвинутого громадянського суспільства і високого рівня політичної культури [3, с. 12-16].

Таким чином, в умовах проведення інформаційної, гібридної війни на території України необхідно комплексно розвивати інформаційну політику держави, створювати механізми протидії пропагандистським закликам, відкрито, прозоро та публічно поширювати об'єктивну інформацію, всебічно захищати журналістів та активіс- тів від посягань на їхнє життя та здоров'я, пов'язаних із професійною діяльністю, розширювати громадський контроль як складник демократичного суспільства.

\section{Висновки}

Основними сучасними важелями негативного впливу на демократію в Україні є: 1) проведення військових дій на території України; 2) нестабільність політичного життя; 3) соціально-економічна, політична, культурна криза; 4) часті порушення прав, свобод та законних інтересів осіб в українському суспільстві; 5) корупція та відсутність ефективних антикорупційних органів; 6) неефективна судова система; 7) неякісна інформаційна політика в державі, внаслідок чого триває гібридна війна; 8) низький розвиток локальної демократії; 9) посягання на свободу слова, в тому числі посягання на життя та здоров'я журналістів, правозахисників та активістів, що пов'язані з професійною діяльністю; 10) недосконалість правового регулювання, несправедливі та негуманні правові норми або їх відсутність; 11) відсутність взаємозв'язку та соціального діалогу між державою та громадськістю; 12) порушення у виборчих процесах; 13) переважання захисту інтересів більш фінансового-сталих верств населення, нерівність у суспільстві.

Усі вищевказані важелі негативного впливу на демократію в Україні можна прибрати шляхом проведення ефективної державної політики у всіх сферах суспільства, припинення військових дій на території України, розвитку освіти та правосвідомості в суспільстві, дотримання принципу рівності, створення тісного взаємозв'язку між державою та громадськістю, забезпечення захисту прав, свобод та законних інтересів осіб, особливо журналістів, активістів та правозахисників, та загалом формування демократії як форми народовладдя.

\section{Список використаних джерел:}

1. Береза В. О. Поняття демократії і демократизації суспільства в сучасному політичному дискурсі. Науковий часопис НПУ імені М. П. Драгоманова. Серія 7 «Релігієзнавство. Культурологія. Філософія». 2015. Вип. 34. С. 143-151.

2. Білодід І.К. Словник української мови : в 11 т. Т. 2 : Г-Ж / ред. тому: П. П. Доценко, Л. А. Юрчук. Київ : Наук. думка, 1970 - 1980. 1971. $550 \mathrm{c}$.

3. Богатирець В. Вплив ЗМІ на демократичні трансформації та процес формування громадської думки. Історико-політичні проблеми сучасного свіmy. 2014. T. 27-28. C. 12-16.

4. Власенко С. Г. Основні причини та ризики деінституціоналізації демократії в Україні та 
шляхи їх подолання. Вісник Національної академіі державного управління при Президентові України. 2015. № 3. С. 131-137.

5. Головатий М. Ф. Демократія: історія, теорія, практика : навчальний посібник. Київ : ДП «Вид. дім «Персонал», 2011. 230 с

6. Громико О. I. Вплив е-демократії на трансформацію системи державного управління в Україні. Актуальні проблеми державного управління. 2016. № 2. С. 42-47.

7. Демократію вбивають 13-й рік поспіль: Чому це відбувається у світі та в Україні за версією Freedom House. 112: інформаиійний веб-сайт. 2019. URL: https://ua.112.ua/golovni-novyni/ demokratiiu-vbyvaiut-13-i-rik-pospil-chomutse-vidbuvaietsia-u-sviti-i-v-ukraini-za-versiieiufreedom-house-479786.html (дата звернення: 06.08.2019).

8. Долженков О. О. Сучасна демократія: проблеми та перспективи. Актуальні проблеми політики : зб. наук. пр. / редкол.: С. В. Ківалов (голов ред.), Л. І. Кормич (заст. голов. ред.), М. А. Польовий (відп. секр.) [та ін.]. Одеса : Фенікс, 2015. Вип. 54. С. 221-229
9. Кривошеїн В. В. Вплив «революції гідності» на політичну та правову культуру українського суспільства. Вісник Начіонального університету «Юридична академія Украӥни імені Ярослава Мудрого». Серія «Політологія». 2016. № 2. С. 37-58.

10.Латигіна H. А. Українська демократія сьогодні: спроби і помилки. Гуманітарний вісник Запорізъкої державної інженерної академї. 2008. Вип. 34. С. 53-62.

11. Латигіна Н. До визначення феномена демократії. Політичний менеджмент. 2004. № 3. C. $20-29$.

12. Freedom House: Democracy in Retreat. Freedom in the world 2019. Freedom House: oфiційний веб-сайт. 2019. URL: https://freedomhouse. org/sites/default/files/Feb2019 FH FITW 2019

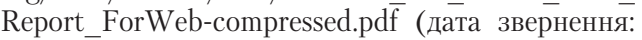
06.08.2019)

13. Freedom House: демократія продовжує свій «відступ». Радіо Собода: інформаційний веб-сайт. 2019. URL: https://www.radiosvoboda. org/a/29750546.html (дата звернення: 06.08.2019).

14. Held David. Models of Democracy. Stanford, California: Stanford University Press, 2006. 234 p.

The article reveals modern levers of negative influence on democracy in Ukraine. The concept of "democracy" is determined as a set of guiding ideas, forms and peculiarities of governance in a state in which the power belongs to the people, that is, with the use of legal mechanisms of compulsory participation of the people in state-management and social processes, with the aim of developing social, political and cultural life of the population the principles of the rule of law, the protection of the rights, freedoms and interests of individuals and society in the state. It is disclosed that the main modern levers of negative influence on democracy in Ukraine are: 1) conducting of military actions on the territory of Ukraine;2) the instability of political life;3) socio-economic, political, cultural crisis; 4) frequent violations of the rights, freedoms and legitimate interests of persons in the Ukrainian society; 5) corruption and lack of effective anti-corruption bodies; 6) ineffective judicial system; 7) inadequate information policy in the state, as a result of which there is a hybrid war; 8) low development of local democracy; 9) attacks on freedom of speech, including attacks on the life and health of journalists, human rights activists and activists related to professional activities; 10) imperfection in legal regulation, unfair and inhumane legal norms, or their absence; 11) the lack of interconnection and social dialogue between the state and the public; 12) violation in election processes; 13) predominance of protection of interests of more financially-stable segments of the population, inequality in society. It is proved that the levers of negative influence on democracy in Ukraine can be eliminated through effective state policy in all spheres of society, the cessation of hostilities in Ukraine, the development of education and legal awareness in society, respect for the principle of equality, the establishment of a close relationship between the state and the public, ensuring the protection of the rights, freedoms and legitimate interests of individuals, especially journalists, activists and human rights defenders, and, in general, the formation of democracy as a form of democracy.

Key words: democracy, information policy, democracy, politics, law, freedom, factors of influence. 